\title{
A Model of Digital Inequality in the Knowledge Society: The Case of Slovenia
}

\author{
Mitja Dečman \\ University of Ljubljana, Faculty of Administration; Ljubljana, Slovenia \\ mitja.decman@fu.uni-lj.si
}

\section{ABSTRACT}

The knowledge society defines information technology (IT) as the crucial factor in accessing knowledge today. At the same time, knowledge itself represents the precondition for using technology. This paradox is linked with the concept of digital inequality, which examines the difference between people in society and includes various levels, such as physical access to technology, possession of the skills to use it, social and cultural influences, and relations between and within these levels. Although the phenomenon of digital inequality is at least two decades old, it has an important role even today. The following paper discusses the notion of digital inequality and links it to information technology access and use in the society. Using the results of 1568 questionnaires completed by a representative sample of Slovenian citizens in 2016, it develops a five-level model that indicates the factors influencing the reasons for the inequalities. The results show that the survey misses the top two levels of the model, but indicate that gender differences are diminishing while income differences significantly influence internet availability, digital skills, and IT use. The results suggest changes in policies that countries should implement to achieve digital inclusion for everyone and consequently the highest possible use of IT and the benefits for society that come with it.

Keywords: digital inequality, knowledge society, information society, digital divide, Slovenia

JEL: 033

\section{Introduction}

Although some authors mark the beginning of the discussion on the information society with the Bangemann Report (Bangemann et al., 1994), the term itself does appear much earlier (Edelstein, Bowes \& Harsel, 1978). The introduction of information technology progressed from occurrences in more closed environments in the era of automatisation to the era of informatisation and the spread of personal computers, first appearing in private and subsequently in the public sector, finally becoming a common part of society at large. This expansion and the subsequent convergence 
of information and communication technology (ICT) continued in the era of the internet and the World Wide Web. Through the digital transformation, the environment developed to the current state, where the internet practically dictates life and enables things that were possible only in science-fiction movies in the past (Kymäläinen, 2016).

The activities of today's society are converging in the direction of non-stop use of information technology (IT) or the constant and silent presence of technology in the 'silent' background, such as the internet of things, big data processing, etc. But society is not homogeneous in this sense. Just as there were differences within the societies of the past, these inequalities persist today in the so-called information society (Yu, 2011), even in the developed and democratic world. This inequality is expressed as digital inequality, which is shown to be a consequence of differences in society and between its residents, and is also the cause of these differences. It is exactly for this reason that we need to think about it today, because the convergence of digital technologies, where 'digital by default' is the mainstream, makes the importance of this issue even greater (Andreasson, 2015, p. 270). This concern is even greater in a global sense, as digital inequalities are connected to the social inequalities of the world. Although knowledge is like light, 'weightless and intangible, it can easily travel the world, enlightening the lives of people everywhere' (World Bank, 1999), many parts of the world are still living in the dark exactly due to digital inequalities.

This paper is focused on today's information society, more specifically on Slovenia, whose current information society status is presented through an analysis of empirical data. Firstly, in the theoretical part we outline the background of digital inequality, discuss the research in this field, and suggest a model of digital inequality. We agree with Misuraca, Codagnone \& Rossel (2013) that existing models of digital inequality research lack impact measurements and cannot explain the persistent state of digital inequality along with the obvious advancement of technology and its usage. In the following chapter, we link the topic of digital inequality to the current situation in Slovenia and the strategies that the county is implementing while developing its information society. The fourth chapter includes an empirical research report and an analysis of data from the surveys, using different statistical methods to correlate measured items and detect influencing factors that divide users into different, unequal, groups. In the discussion section, we argue that the results show a situation valid for many developed countries. The influence of gender is diminishing, but the impact of socio-economic status is persistent and significant. We also argue that the suggested model needs to be empirically tested, but we predict that the results would provide a holistic picture of digital inequalities, especially the impact thereof, and would as well provide information to policy-makers to enable them to take the right steps to an all-inclusive information society. 


\section{Theoretical Background}

The information society started developing in the nineties, when information technology and the emerging internet started to penetrate the wider social environment from the academic and private sectors (Van Dijk \& Hacker, 2003). At the same time, the moment coincided with other social, economic, and cultural transformations (Castells, 2011). Ambassadors such as Bangemann and Gore saw the information society as the next serious shift of human society (Bangemann et al., 1994; Loader, 1998, p. 150). The OECD (2010) defined the information society in terms of a conceptual model of the relationship between supply and demand, where the supply side is represented by the IT sector of suppliers, with a clear influence on productivity and GDP, while the demand side is actualised through the use of IT and e-services by citizens and the public and private sectors. Webster (2014, p. 10) saw the information society through a technological, economic, occupational, spatial, and cultural prism, sharing the conviction that quantitative changes in information are bringing about this qualitatively new sort of social system. Misuraca et al. (2013) claim that the information society emerged out of IT use in the realm of firms and then became broadly pervasive in the whole of society, with such use being focussed on the socio-economic impacts. While the private sector is primarily oriented towards monetary measures of IT expenditure, the information society includes the availability, access, adoption, usage, and impact of IT on society as a whole (Misuraca et al., 2013).

Some authors orient their discussion towards the term knowledge society, trying to stress that IT is the fundamental source of knowledge (Karpov, 2017) and 'chiselled' into a social system in such a manner that it represents the foundation of its stability (Stehr, 2007). Knowledge is the key good and power of the individual and causes a revolutionary reshaping of society (Mehmood, Rehman \& Haider Rizvi, 2014). At the same time, Duff (2013, p. 174) stresses that many theorists equate the information society with the knowledge society, although knowledge is an upgrade or a higher-level entity than information and they should not be treated as synonyms.

We can agree that knowledge is the power of today's society and the individuals within it. Gaining knowledge depends on the availability of IT and the capability of individuals to use it, which influences their material outcome in the end. Van Dijk (2012) goes even further and claims that the final material state is in fact the beginning and therefore a condition to access ever-new technology and knowledge. While in todays developed world almost anyone can afford at least basic access to the internet, a device to use it on, and has some basic digital skills, there is a much smaller proportion of those who can afford the newest and fastest devices and tools and the highest level of broadband available. These are usually the ones who use the internet in a manner that has a high impact on their material status. 
So-called digitally literate individuals are the crucial element of the knowledge society. These citizens can communicate digitally, use digital sources, are innovative, and create new knowledge and solutions. The idea of a successful information and knowledge society therefore entails ensuring the digital inclusion of each and every individual and consequently his or her welfare. But as Wessles et al. claim (2016), the real transformation to a knowledge society has not yet happened.

\subsection{Digital Inequality}

Descriptions of the inequality of an individual, organisation, or even a geographic area in the knowledge society is often termed the digital divide, digital inequality, information divide, information poverty, or even knowledge gap (Yu, 2011). Robinson (2012), for example, defines digital inequality as a wider phenomenon compared to the digital divide. The digital divide, as an important parameter of the knowledge society, focuses on differences in the access to and use of information technology and e-services (Servaes \& Oyedemi, 2016, p. 27). The phenomenon covers the areas of the private sector, the public sector, and citizens. Tilly (1998) explains it as an inequality as regards resource distribution in a society as the result of competition between pairs of social categories, such as male-female, educated-uneducated, oldyoung, rich-poor, etc. Some authors define the characteristics of the digital divide as those that separate today's society from the industrial society of the past (Sparks, 2013). According to the OECD definition, the digital divide is the gap between individuals, households, organisations, or geographical areas with different socio-economic levels considering access to information communication technology and use of the internet for different activities (OECD, 2011). Today, some researchers add the aspect of 'motivation to use IT' to the concept of the digital divide (Van Dijk, 2012).

The first researchers of the digital divide focused primarily on the level of unequal access to technology, particularly the internet, and its use (DiMaggio, Hargittai, Celeste \& Shafer, 2004). But the concept developed subsequently with the addition of levels such as the inequality of digital skills and literacy together with psychological and socio-cultural limitations and differences (DiMaggio et al., 2004; van Deursen \& Van Dijk, 2011; Van Dijk \& Hacker, 2003).

\subsection{The Levels of Digital Inequality}

From the viewpoint of the first level of digital inequality (Figure 1), i.e. unequal access to information technology and the internet, researchers have understood the divide literally as a border between those that have and those that have not, set in the direction of technological determinism (Gunkel, 2003). The first studies on the digital divide showed that access to technology is lower for women, the rural population, older generations, and those with less knowledge and income, which applied to the developed parts of Northern and Western Europe even at the beginning of the 21st century (Van Dijk, 
2005). Even in the United States around the year 2008, $53 \%$ of individuals in households with less than USD 30,000 of annual income, 63\% of the rural population, $44 \%$ of individuals with only lower education, and $35 \%$ of those age 65 or older used the internet only occasionally (PEW, 2008). On the other hand, newer studies have shown that households in developed countries with fast broadband access have a greater chance of increasing household income (Rohman \& Bohlin, 2013). In OECD countries, a 10 percentage point increase in broadband penetration can increase GDP growth by $0.9 \%$ to 1.5\% (Czernich, Falck, Kretschmer \& Woessmann, 2011). The International Telecommunications Union (ITU), located in Geneva, Switzerland, reports that a huge obstacle to broadband access to the internet is the economic status of the individual (International Telecommunications Union, 2016). The ITU's goal is for the world to achieve a state where the cost of broadband service would be no more than $5 \%$ of the average monthly income in developing countries by 2020. In other words, this means that one would have to work 1.5 days each month to cover one's internet subscription, which is still significant. Nonetheless, the research of Weiss et al. (2016) showed that in the countries where the level of income and education is higher, the cost of accessing the internet is also more accessible. Finally, it has been determined that in the developed world access to the internet no longer represents a major obstacle and that we are approaching an era where people will refuse to have internet access only because they want it that way (Van Dijk, 2012).

Figure 1. The digital inequality model $(3+2)$ and its types of influences

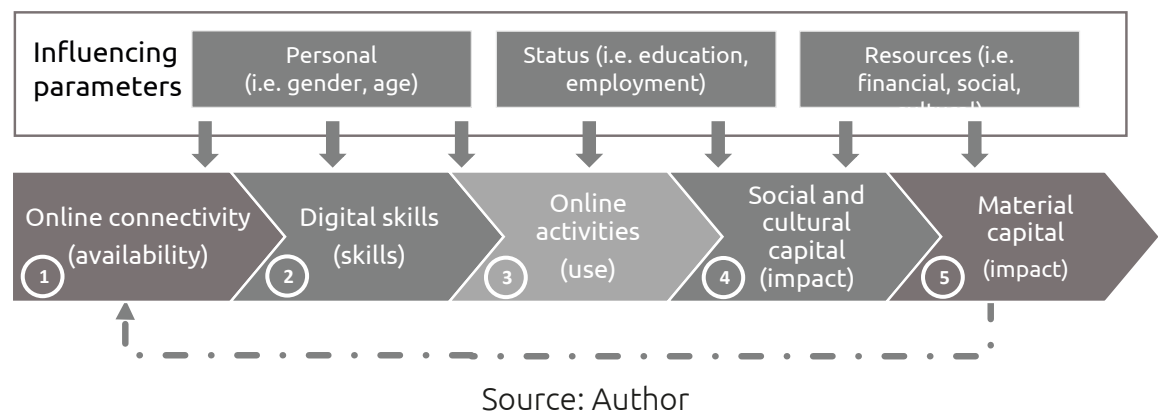

The second important level of digital inequality (Figure 1) is that of digital skills and knowledge. Van Deursen, Helsper, and Eynon (2016) classified these skills as operational and navigation information, and social, creative, and mobile skills. Schradie (2011) proved in her research that inadequate access to technology and access to the internet (or low speed internet access) can indirectly influence the development of digital skills, where a lack of these skills can then further widen the gap and cause lower participation in the internet environment. In addition, digital skills are important for more reasons than just the use of IT and the internet. Witte and Mannon (2010, p. 113) proved that more competent users can easily move from one website to another and are able to take advantage of more useful and advanced 
possibilities, which makes the concept of digital inequality parallel to the social class inequality of Max Weber. By direct use and execution of beneficial tasks, these users have an even greater advantage in the private and professional environment. As regards the public sector, users with more developed digital skills express higher satisfaction with e-government services (Ebbers, Jansen \& van Deursen, 2016). With the increased convergence of IT in the future, we can expect that digital skills will become a vital element of modern society and mark the position of an individual within society (van Deursen \& Van Dijk, 2011).

The third level of digital inequality (Figure 1) focuses on the benefits of digital inclusions based on internet access and possession of digital skills, excluding socio-cultural and material impacts. Schradie's (2011) research reports that consistent and frequent online access does lead to higher productive usage regarding all activities. While many users might have a similar or even equal environment as to internet access and levels of digital skills, the way they use them might differ. Even 'digital natives', as the young population born into the environment of the internet is often called, achieve different things while being online. Hargittai (2010) claims that people develop only those skills that they need to use the internet within their fields of interest, stressing the relationship between the type of use and the socio-economic status of the individual. Similarly, Capgemini (2016) detected that in Great Britain the digital skills of youth are inadequate for the jobs awaiting them since their use and corresponding usage are not appropriate for those environments. Beside personal interest, reasons can also be found in the social and cultural factors of individuals and society. In their research, Brandtzæg, Heim \& Karahasanović (2011) separated the study participants into different groups according to their type of usage, namely non-users, sporadic users, entertainment users, instrumental users, and advanced users, and showed a significant correlation with the predictors of age, gender, and number of household members. Studies have shown that a positive correlation exists between the level of general internet use and the level of use of specific internet services, e.g. use of e-government services (Fernández-i-Marín, 2011). And finally, not every citizen wants to use IT and the internet. Not only are there those who do not need it, but also those who consciously reject it and use no such services.

The two highest levels of the model focus on the impact of digital exclusion or inclusion. These can be cultural-social or material. Digital inclusion can, for example, give an individual an advantage when competing for a job and changing his or her social status from unemployed to employed in that sense. Already in 2003, Van Dijk and Hacker (2003) ascertained that 'in the information and network society, relative differences in getting information and lines of communication become decisive for one's position in society, more than in every society in history before.' This is then also related to the individual's material situation. Evangelista, Guerrieri \& Meliciani (2014) describe this economic impact of ICT in the composite indicator of 'empowerment of an 
individual' in day-to-day life in key social and economic domains. Morganti et al. (2014) claim that the maximum economic impact of the information society can only be achieved through a holistic set of policies ranging from telecoms and computing, to the adoption of the internet and e-commerce. A Eurostat analysis shows that the digitally literate will also have a higher chance of becoming experts in the areas related to or dependant on IT and therefore are a workforce group for which demand has been growing since 2006 at a rate of 3\% annually (Eurostat, 2016). And Sparks (2013) concludes that serious online activities increase the social and cultural capital of the user, which can be linked to an increase in material capital. Sadly, empirical research on this level is rare and even the most well known indexes of the information society lack this kind of measurement and analysis.

\subsection{Information Society Indexes - Digital Inequality Gap Detection}

Through the years of development of the information society different indexes and benchmarking systems have appeared to analyse, promote, and encourage the use of IT and the internet, on the national and international levels. In Europe, one of the first was the so-called e-Europe benchmarking, which subsequently developed into the DESI Index. Another important international index is the Network Readiness Index (NRI) (World Economic Forum, 2016). The Network Readiness Index sets a final grade between 0 and 7 , but countries have been achieving levels between 2.2 and 6 in recent years. The Index is composed of four categories, namely the Environment sub-dimension (countries achieve scores between 2.6 and 6), the Readiness sub-dimension (countries achieve scores between 1.9 and 6.6), the Usage sub-dimension (countries achieve scores between 2.1 and 6), and the Impact sub-dimension (countries achieve scores between 2.1 and 6.1). Differences in the indexes of individual states show huge gaps between most developed countries and those lagging behind. The latest report stressed that digital technologies are the basis of innovation in the digital revolution era and that the most innovative countries have a high level of IT adoption in businesses. The report confirms the rapidly growing digital population, which demands more than business can offer and more than governments are offering through different e-services.

Another index is provided by the International Telecommunication Union, which is a special agency of the United Nations in charge of information and telecommunications technology. In its report in 2016 (International Telecommunication Union, 2016) it shows a regional gap where the percentage of internet users in developing countries is $40.1 \%$, while in the developed countries the percentage is $81 \%$. The report stresses that mobile phone coverage is now nearly ubiquitous, with an estimated $95 \%$ of the global population enjoying phone coverage, with $53 \%$ of the global population having advanced mobile broadband networks (LTE) available. In many countries, mobile broadband prices are lower than fixed broadband 
prices. But digital inequality is here to stay for a while, since half of the world's population still does not use the internet and gender differences are still significant.

The European Union created the Digital Economy and Society Index - DESI to evaluate the state of EU countries in the area of the digital economy and digital society. The DESI Index is composed of five areas: Connectivity, Human Capital/Digital Skills, Use of the Internet by Citizens, the Integration of Digital Technology by Businesses, and Digital Public Services (European Commission, 2017). It enables an evaluation of the countries' state of affairs in this area, shows the areas of possible improvements, and evaluates achievements over time (indicators are fixed and standardised; therefore, they enable comparisons between Member States or groups of Member States).

Nevertheless, the researchers established (Evangelista etal., 2014) that indexes of different national or international agencies analyse too heterogeneous, non-standardised, and often inadequate data to conduct an adequate analysis of digital inequality. In the area of e-government benchmarking, critics warn that e-government indexes mostly measure the offer or ex-ante existence of websites and services in all countries and environments, without focusing on specifics (Bannister, 2007; Misuraca et al., 2013; Whitmore, 2012). They propose the obligatory measurement of the use of online services or online procedures as a supplement to user surveys, which is achieved to a smaller degree by the DESI Index. The latest models, such as eGEP and eGEP2.0 (Savoldelli, Misuraca \& Codagnone, 2013), on the other hand, have not been widely accepted although they are focused exactly on the measurement of e-government impacts (impact assessment models).

\section{The Information Society of Slovenia}

Slovenia realised the potential of IT at the end of the 1990s and in the year 2000 adopted a law that equalised electronic and paper documents and signatures and opened the path to e-business, e-government, and the information society. However, at the same time it was determined that digital inequality exists in Slovenia, as in many other places in the world, depending on social status and education (Robinson et al., 2015).

Slovenia is a country with low and dispersed population density in the majority of its territory. Urban areas ( 163 communities or $3 \%$ of all communities) cover just $4 \%$ of the territory of Slovenia, but host $45 \%$ of the population. Over the years, Slovenia has developed and upgraded the information technology infrastructure and access thereto. Today, telecommunications, road, railway, and electricity companies manage a good network backbone with optical fibres. The coverage of the mobile broadband signal is increasing and the minimisation of white areas has successfully included the upgrade to LTE and 4G networks. Nonetheless, according to the data of the Agency for Communication Networks and Services of the Republic of Slovenia (2017), 
only $29.7 \%$ of the population had fixed broadband access in 2016, equal to $74.9 \%$ of households. Both indexes are below the EU average. Countries such as Germany, the Netherlands, and Denmark had more than $80 \%$ of households connected to fixed broadband internet in 2010. Nevertheless, Slovenia is ranked in the upper half of countries in terms of internet penetration. In the latest Networked Readiness Index report of 2016, the World Economic Forum (2016) ranked Slovenia in $37^{\text {th }}$ place out of 139 countries. With an index of 4.7 out of 6 , it lags behind the best by a significant amount. Focusing on the index subcategories, it is ranked quite high in the Readiness sub-dimension (25th place) and the Impact sub-dimension (37th place), but lower in the Environment sub-dimension (45th place) and Usage sub-dimension (42nd place). Considering the digital inequality area within the Readiness sub-dimension, it has a better rank for Skills ( $21^{\text {st }}$ place) and Infrastructure and Digital Content (24th place), buta low $60^{\text {th }}$ rank for Affordability. The best places in terms of affordability are in Asian countries with low GDP; nonetheless once can find reasonably priced internet access in Austria, Finland, and the USA. The latest developments on the Slovenian market show that market competition, primarily on the mobile data market, may reduce prices considerably. Another obstacle in Slovenia is the bad political and regulatory environment (67th place) and the very low use of e-government services (86 th place), incorporating the importance of ICTs into the Government's vision for the future, the Government's success in ICT promotion, and the Government's Online Service Index. The Europeanlevel DESI Index 2017 ranks Slovenia in 17th place out of 28 countries, which is the same rank as in 2014. Again, the lowest score was for the Internet Use sub-dimension (23rd place), since the level of different online services is low, including e-banking and online shopping. The digital skills of the Slovenian population are ranked approximately $15^{\text {th }}$ best in Europe.

The future plans and strategies of Slovenia are described in the Development Strategy for the Information Society until 2020 (Government of the Republic of Slovenia, 2016a). As stated in the Strategy, although Slovenia adopted some legislation, strategies, action plans, and projects related to exploiting developmental opportunities, including the potential of ICT and the internet, these were insufficiently revolutionary or fast enough to develop the information society on a full scale. The current first goal of this strategy is to upgrade and develop an adequate infrastructure to guarantee a fast internet connection to all citizens. According to Slovenia's Next-Generation Broadband Network Development Plan until 2020 (Government of the Republic of Slovenia, 2016b), $96 \%$ of households in Slovenia will have at least a 100 $\mathrm{Mb} / \mathrm{s}$ internet connection by 2020, and the other $4 \%$ at least $30 \mathrm{Mb} / \mathrm{s}$. Using European funding for the development of the countryside, it will provide the rural population and business with faster internet access. 


\section{Empirical Research - the Case of Slovenia}

\subsection{Methodology}

The questionnaire used in this paper is a part of the Community Survey on ICT Usage in Households and by Individuals conducted by the Statistical Office of the Republic of Slovenia as part of pan- European research. The results of the survey are also used for the already-mentioned pan-European DESI Index. The yearly questionnaire includes questions that are included in the survey every year (or every second year) and used to track the development of a more general агеa, and questions that focus on a specific topic, defined by the current needs of the country's policies. In the year 2014 the focus was on the usage of cloud services, in 2015 on e-shopping, in 2016 on the submission and protection of personal data on the internet, and in 2017 on the usage of digital certificates and online services that use them. Most of the questions are targeted at users who are between 10 and 74 years of age and used the internet in the previous 3 months (or in some cases in the last 12 months).

Although most of the questions are defined by the European Commission and Eurostat and are also based on the OECD model for measuring the information society, the real question is whether they map the characteristics or levels of digital inequality. The indexes of information society development in the EU show constant progress over the last five years, including the level of internet availability and number of internet users, but there is still no solid proof that this influences changes in society or not. Researchers are trying to find reasons in unsuitable models, the inadequate impacts shown by such indexes, or the inappropriate data gathered thereby (Misuraca et al., 2013). We believe that these questions can be linked to the issues of digital inequality but do not provide a holistic picture.

The questionnaire generates 161 independent variables, excluding demographics. Most of the variables are binary, i.e. dichotomous, which lowers the range of possible statistical analysis or in some cases demands the reshaping of the variables. Therefore, the following analysis includes the basic statistical analysis, including the analyses of dependency between the individual measured variables and demographic variables. The results are focused on users that used the internet in the previous 3 months $(N=1138)$ since we would like to focus on the inequalities between the existing users of the internet, having in mind that Slovenia is a developed country with high internet availability (fixed and mobile). Out of 1568 survey respondents we therefore excluded those that never used the internet $(n=389)$ or used it more than 12 month ago or 3 to 12 month ago ( $N=28, N=13$, respectively). Nevertheless, it was determined that among those respondents who do not use the internet, $13.5 \%$ do have access in their household, but it is used by other members of the household. Among those who do not have any household access ( $N=212), 73.1 \%$ of them stated that they do not need it. 


\subsection{Results and Analysis}

The results show that users connect to the internet primarily through smart phones (70.7\%), followed by laptop (69.5\%) and desktop (57.4\%) computers, while only $29.7 \%$ use tablet computers to connect to the internet. Although we discuss only those users that use the internet regularly, we also focused on inequalities depending on gender, age, and household income level between users and non-users of the internet (the first level of the model, see Figure 1). A significant association between internet use and gender does not exist. This was checked using a Mann-Whitney $U$ test $(U=160215, z=-.466$, asymptotic $p=.641$, the distribution for both genders being visually similar). A chi-squared test of homogeneity was used to test the differences in terms of household income class. Significant differences were confirmed between users and non-users, as in the lowest household income class only $47.2 \%$ were users, while in the highest household income class $92.6 \%$ were users (Table 1 ). Also significant, but in the reverse order, was the relation between usage and age, where in the oldest age class only $33.8 \%$ were internet users compared to $97.9 \%$ in the youngest class (Table 2). It is important to note that within the working population group aged $55-65$ only $54.4 \%$ use the internet.

Table 1. The percentage of internet users with statistically significant differences between household income classes (average net monthly income considered)

\begin{tabular}{|l|c|c|c|c|c|c|}
\hline Variable & $p$ value & $\begin{array}{c}\text { Class 1- } \\
€ 900 \text { or less }\end{array}$ & $\begin{array}{c}\text { Class 2- } \\
€ 901-1300\end{array}$ & $\begin{array}{c}\text { Class 3- } \\
€ 1301-1700\end{array}$ & $\begin{array}{c}\text { Class 4- } \\
€ 1701-2100\end{array}$ & $\begin{array}{c}\text { Class 5 - } \\
\text { more than } \\
€ 2100\end{array}$ \\
\hline $\begin{array}{l}\text { Internet } \\
\text { users }\end{array}$ & $p<.001$ & $47.2 \% \mathrm{a}$ & $68.3 \% \mathrm{~b}$ & $83.4 \% \mathrm{c}$ & $92.3 \% \mathrm{c}, \mathrm{d}$ & $92.6 \% \mathrm{~d}$ \\
\hline
\end{tabular}

Note: Groups with the same subscript letter are not significantly different.

Source: Author

Table 2. The percentage of internet users with statistically significant differences between age classes

\begin{tabular}{|l|c|c|c|c|c|c|c|}
\hline Variable & $p$ value & $\begin{array}{c}25 \text { years } \\
\text { or less }\end{array}$ & $26-35$ & $36-45$ & $46-55$ & $56-65$ & $\begin{array}{c}66 \text { or } \\
\text { more }\end{array}$ \\
\hline $\begin{array}{l}\text { Internet } \\
\text { users }\end{array}$ & $p<.001$ & $97.9 \%$ & $99.1 \%$ & $92.8 \%$ & $79.7 \%$ & $54.4 \%$ & $33.8 \%$ \\
\hline
\end{tabular}

Note: Groups with the same subscript letter are not significantly different.

Source: Author

The main focus of our research was on users of the internet. At the inequality level of digital skills (the second level of the model, see Figure 1) the questionnaire included two groups of questions. In the first group, the questions are directly related to the skills of specific software-related activities in the sense of 'Have you used a software application for ... ?', while in the second category they are indirectly related to skills in the sense of service use, e.g. 'Have you played/watched/paid for, etc.,?'. Since we were unable to pose these questions, we do have a criticism regarding them. The questions used in this survey have an issue as to the notion of those who actually use 
and those who have the knowledge to use it but do not. Namely, positive answers to the 'usage questions' do not detect those respondents who can use but did not (in the previous three-month period). In this sense, we can report the following levels of usage among respondents (Figure 2):

- The highest percentage of use, and therefore knowledge to perform such activities, was quite understandably shown for e-mail, followed by finding online information on goods and services and reading online news, newspapers, or magazines. These services are easy to use and require a low level of digital skills as well.

- The lowest level of usage was detected for technically demanding activities of content creation (websites, blogs) that demand a higher level of digital skills, the use of online payment systems such as PayPal, showing a possible issue of trust, and the use of online forms to arrange appointments with a general practitioner. The latter result is explainable by the fact that online forms in this context are гаге in Slovenia and e-health services are a very new trend in Slovenia since the recently established e-health system is still in development.

Figure 2. Percentage of users carrying out a specific activity on the internet in the previous three months $(N=1138)$

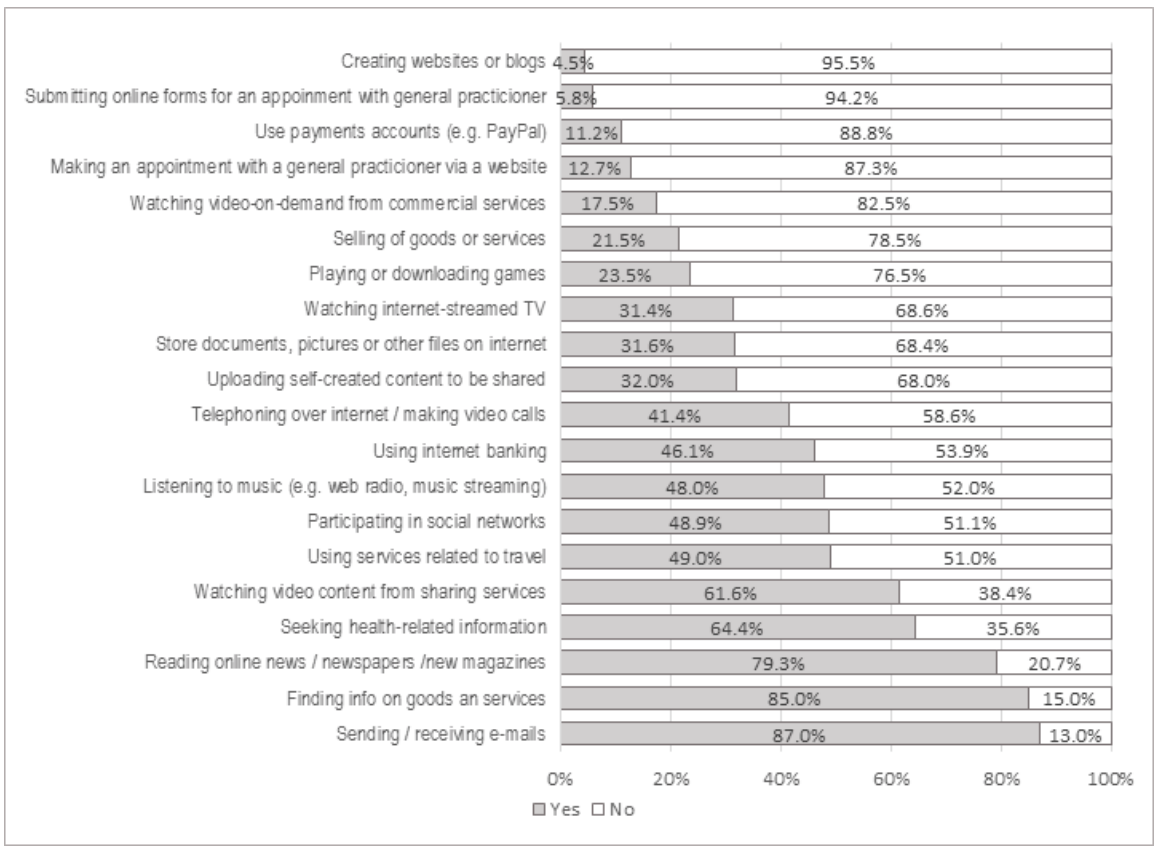

Source: Author

The data on users' activities entailing use of a specific software application show that respondents use and know how to use word processing software the most and presentation software the least, which in some ways corresponds 
to an average user's needs in his or her personal or professional life. The level of code writing or programming is very low, thus representing a demanding task for an average user. Considering operational computer skills, most users manage simple skills such as transferring files between devices, but rarely (dare) to change system or software settings (Table 3).

Table 3. Percentage of users carrying out specific activities based on digital skills.

\begin{tabular}{|c|c|c|c|c|c|c|c|c|}
\hline 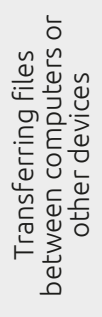 & 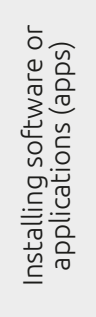 & 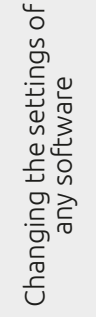 & 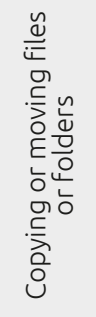 & 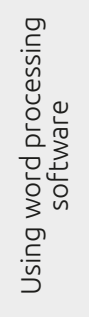 & 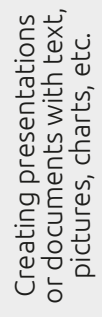 & 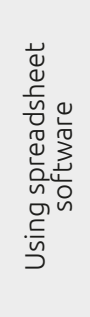 & 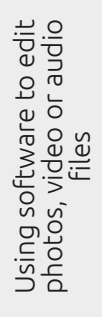 & 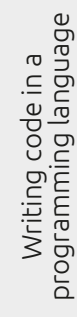 \\
\hline $62.9 \%$ & $40.6 \%$ & $26.7 \%$ & $68.1 \%$ & $70.2 \%$ & $54.5 \%$ & $38.6 \%$ & $41.7 \%$ & $6.8 \%$ \\
\hline
\end{tabular}

Especially interesting results were found in the area of public sector services (including the services of libraries, schools, universities, municipalities, healthcare centres, etc.), where $53.1 \%$ of respondents visited websites (this does not concern online applications, forms, or the use of digital signatures). This is only $5 \%$ more than those who use online banking, which from a technological point of view is a much more demanding service and, regarding trust, a more critical service. On the other hand, online banking is, of course, a more useful service in everyday life. Only $37.7 \%$ of users download official public sector web forms, and only $27.5 \%$ submit these forms online. In this case, we suspect that this mainly concerns public administration forms since forms related to health institutions, libraries, or other institutions do not exist online to such an extent or these services need a personal approach (a physical exam, a physical book). Of those users who do not use online official forms ( $N=881$ or $77.4 \%$ ), only $27.5 \%$ had been in a situation where they had to submit a form (physically or electronically). The most common reason for not submitting such in electronic form was technical since $40.5 \%$ of users claim that they did not do so because they do not have a digital certificate or because of the trouble using it (Table 4). 
Table 4. The reasons for not submitting completed forms to public authority websites

\begin{tabular}{|c|c|c|c|c|c|}
\hline 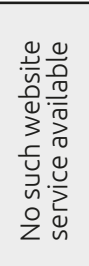 & 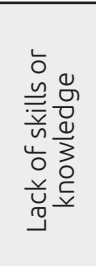 & 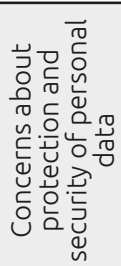 & 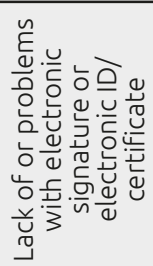 & 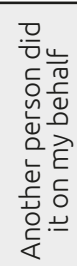 & 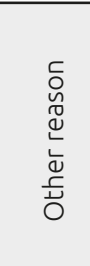 \\
\hline $14.9 \%$ & $13.6 \%$ & $21.9 \%$ & $40.5 \%$ & $9.9 \%$ & $24.4 \%$ \\
\hline
\end{tabular}

Source: Author

We further analysed the impact of different demographic parameters on digital inequality. In order to determine inequalities between males and females, we used a Chi-square test for association (using a $2 \times 2$ contingency matrix) and satisfied the assumptions by ensuring the independence of observations, variables that are measured at the categorical level, and that all cells of the table have an expected count greater than five. The results show a statistically significant association between gender and:

- (activity carried out)

- sending/receiving e-mails $-X^{2}(1)=4.505, p=.034$, weak association $-\phi=-.063$ (men carry out this activity less than women $-84.8 \%$ vs. $89.2 \%), p=.034$;

- seeking health-related information $-X^{2}(1)=32.944, \quad p<.001$, moderate association $-\phi=-.170$ (men carry out this activity less than women $-56.1 \%$ vs. $72.4 \%), p<.001$;

- making an appointment with a general practitioner via a website $X^{2}(1)=4.925, p=.026$, weak association $-\phi=-.066$ (men carry out this activity less than women $-10.5 \%$ vs. $14.9 \%), p=.026$;

- selling of goods or services $-X^{2}(1)=13.239, \quad p<.001$, weakly moderate association $-\phi=.108$ (men carry out this activity more than women $-26 \%$ vs. $17.2 \%), p<.001$;

- playing or downloading games $-X^{2}(1)=12.608, p<.001$, weakly moderate association $-\phi=.105$ (men carry out this activity more than women $-28 \%$ vs. $19.1 \%), p<.001$;

- creating websites or blogs $-X^{2}(1)=5.072, p=.024$, weak association $-\phi=.067$ (men carry out this activity more than women $-5.9 \%$ vs. $3.1 \%), p=.024$;

- using payment accounts (e.g. PayPal) $-X^{2}(1)=6.360, p=.012$, weak association $-\phi=.075$ (men carry out this activity more than women $-13.5 \%$ vs. $8.8 \%), p=.012$;

- watching internet-streamed TV from TVbroadcasters $-X^{2}(1)=5.901$, $p=.015$, weak association $-\phi=.015$ (men carry out this activity more than women $-34.8 \%$ vs. $28.1 \%), p=.015$; 
- (software skills)

- installing software or applications (apps) $-X^{2}(1)=13.768, p<.001$, weakly moderate association $-\phi=.110$ (men carry out this activity more than women $-46.5 \%$ vs. $35.7 \%$ ), $p<.001$;

- changing the settings of any software $-X^{2}(1)=28.068, p<.001$, moderate association $-\phi=.157$ (men carry out this activity more than women $-34 \%$ vs. $20.1 \%), p<.001$;

- using presentation software $-X^{2}(1)=4.209, \quad p=.040$, weak association $-\phi=-.061$ (men carry out this activity less than women $-36 \%$ vs. $41.9 \%), p=.040$;

- writing code in a programming language $-X^{2}(1)=23.251, p<.001$, moderate association $-\phi=.143$ (men carry out this activity more than women $-10.5 \%$ vs. $3.3 \%), p<.001$.

The second common parameter of digital inequality is based on monthly household income. This dependence was tested with a chi-square test of homogeneity. The assumptions of the test are tenable since we have one dependent variable that is measured at the dichotomous level, one independent variable that has three or more categorical and independent groups, independence of observations, a large enough sample $(N=921)$, and all cells of the $2 \times C$ table have an expected count greater than or equal to five. The results show a statistically significant difference based on monthly household income groups and almost all measured items. The variables of selling goods or services; participating in social networks; playing or downloading games; using advanced functions of spreadsheet software; and writing code in a programming language did not show statistically significant differences. All other measured variables showed statistically significant differences between groups when applying a pairwise comparison (Group 1 $€ 900$ or less, Group 2-€901-1300, Group 3 - €1301-1700, Group 4 - €17012100, Group 5 - more than $€ 2100$ average net monthly household income)'. Post hoc analysis involved pairwise comparisons applying a z-test of two proportions with a Bonferroni correction (shown in Table 5). For example, a statistically significant difference in proportions, $p<.001$, of a higher level of desktop computer use with Group 5 (68.4\%) was detected in comparison to Group 1 (45.4\%) and Group 2 (49.2\%).

1 The groups were of unequal sizes.

Mednarodna revija za javno upravo, letnik 15, št. 2/2017 
Table 5. Percentage of 'Yes' responses for statistically significant differences between household income groups

\begin{tabular}{|c|c|c|c|c|c|c|}
\hline Variable & $\frac{\stackrel{n}{J}}{\stackrel{0}{2}}$ & 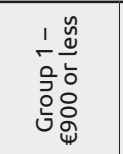 & 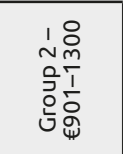 & 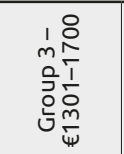 & 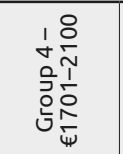 & 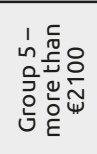 \\
\hline $\begin{array}{l}\text { Using the internet on a desktop } \\
\text { computer }\end{array}$ & $p<.001$ & $45.4 \%$ a & $49.2 \%_{a}$ & $58.0 \%_{a, b}$ & $57.1 \% \mathrm{a}, \mathrm{b}$ & $68.4 \% \mathrm{~b}$ \\
\hline $\begin{array}{l}\text { Using the internet on a laptop or } \\
\text { notebook }\end{array}$ & $p<.001$ & $60.0 \%$ a & $61.6 \%$ a & $64.4 \%$ a & $73.8 \% \mathrm{a}, \mathrm{b}$ & $82.8 \% \mathrm{~b}$ \\
\hline Using the internet on a tablet & $p<.001$ & $20.0 \% a, b$ & $21.1 \% \mathrm{~b}$ & $23.9 \% a, b$ & $34.5 \%$ a,c & $43.2 \%_{c}$ \\
\hline $\begin{array}{l}\text { Using the internet on a mobile or } \\
\text { smart phone }\end{array}$ & $p<.001$ & $63.8 \%$ a & $67.0 \%$ а & $63.3 \%$ a & $74.4 \% a, b$ & $80.8 \% \mathrm{~b}$ \\
\hline Sending / receiving e-mails & $p<.001$ & $73.1 \%$ a & $80.0 \% a, b$ & $86.7 \%$ b,c & $92.9 \%_{\mathrm{C}}$ & $94.4 \% c$ \\
\hline Using internet banking & $p<.001$ & $30.0 \%$ a & $40.0 \% a, b$ & $47.3 \% \mathrm{~b}$ & $47.6 \%$ b & $65.6 \% c$ \\
\hline $\begin{array}{l}\text { Finding info on goods and } \\
\text { services }\end{array}$ & $p<.001$ & $81.5 \%$ a & $77.3 \%$ a & $84.0 \% a, b$ & $85.7 \% a, b$ & $92.0 \% \mathrm{~b}$ \\
\hline $\begin{array}{l}\text { Seeking health-related } \\
\text { information }\end{array}$ & $p=.003$ & $58.5 \%$ a & $56.8 \%$ a & $68.6 \% a, b$ & $64.3 \% a, b$ & $72.8 \% \mathrm{~b}$ \\
\hline $\begin{array}{l}\text { Making an appointment with a } \\
\text { general practitioner via a website }\end{array}$ & $p<.001$ & $10.8 \% a, b$ & $4.3 \% \mathrm{~b}$ & $14.4 \%$ a & $12.5 \% a, b$ & $18.4 \% \mathrm{a}$ \\
\hline $\begin{array}{l}\text { Submitting online forms for an } \\
\text { appointment with a general } \\
\text { practitioner }\end{array}$ & $p=.031$ & $3.8 \% a, b$ & $2.2 \% \mathrm{~b}$ & $6.9 \% \mathrm{a}, \mathrm{b}$ & $6.5 \% a, b$ & $9.2 \%$ a \\
\hline $\begin{array}{l}\text { Reading online news / } \\
\text { newspapers / news magazines }\end{array}$ & $p=.018$ & $74.6 \%$ a & $76.8 \%$ a & $75.5 \%$ a & $83.3 \%$ a & $85.6 \%$ a \\
\hline $\begin{array}{l}\text { Telephoning over the internet / } \\
\text { making video calls }\end{array}$ & $p=.004$ & $40.0 \% a, b$ & $36.2 \% \mathrm{~b}$ & $34.0 \%$ b & $42.3 \% a, b$ & $50.8 \% \mathrm{a}$ \\
\hline $\begin{array}{l}\text { Uploading self-created content to } \\
\text { be shared }\end{array}$ & $p<.001$ & $26.2 \%$ a & $28.6 \%$ a & $27.1 \%$ a & $33.3 \% a, b$ & $43.2 \% \mathrm{~b}$ \\
\hline Using services related to travel & $p<.001$ & $30.8 \%$ a & $38.9 \% a, b$ & $49.5 \%$ b & $48.8 \%$ b & $69.2 \%_{c}$ \\
\hline Listening to music & $p<.001$ & $36.9 \%$ a & $43.8 \%$ a & $47.3 \% a, b$ & $52.4 \% a, b$ & $59.6 \%_{c}$ \\
\hline Creating websites or blogs & $p<.001$ & $3.1 \%$ a & $2.2 \%$ a & $2.7 \% \mathrm{a}$ & $7.1 \%$ a & $7.6 \% \mathrm{a}$ \\
\hline $\begin{array}{l}\text { Using payment accounts to pay } \\
\text { for goods or services }\end{array}$ & $p<.001$ & $9.2 \% a, b$ & $8.6 \% b$ & $6.4 \% b$ & $13.7 \%$ a,b & $18.8 \%$ a \\
\hline Watching internet-streamed TV & $p<.001$ & $17.7 \%$ a & $22.2 \% a, b$ & $29.8 \% a, b$ & $34.5 \% a, b$ & $45.6 \%_{c}$ \\
\hline $\begin{array}{l}\text { Watching video-on-demand from } \\
\text { commercial services }\end{array}$ & $p=.012$ & $10.0 \%$ a & $15.1 \% a, b$ & $16.0 \% a, b$ & $19.6 \% a, b$ & $23.6 \% b$ \\
\hline $\begin{array}{l}\text { Watching video content from } \\
\text { sharing services }\end{array}$ & $p<.001$ & $55.4 \%$ a & $53.0 \%$ a & $55.3 \%$ a & $64.9 \% a, b$ & $70.8 \% \mathrm{~b}$ \\
\hline $\begin{array}{l}\text { Using cloud storage space on the } \\
\text { internet }\end{array}$ & $p<.001$ & $22.3 \% \mathrm{a}$ & $21.1 \% \mathrm{a}$ & $26.1 \% \mathrm{a}$ & $42.9 \%$ b & $48.4 \% \mathrm{~b}$ \\
\hline $\begin{array}{l}\text { Obtaining information from } \\
\text { public sector websites }\end{array}$ & $p<.001$ & $43.3 \% a, b$ & $38.6 \% \mathrm{~b}$ & $48.7 \%$ a,b & $56.5 \%$ a & $72.8 \%_{c}$ \\
\hline $\begin{array}{l}\text { Downloading official forms from } \\
\text { public sector websites }\end{array}$ & $p<.001$ & $23.9 \% a, b$ & $21.7 \% \mathrm{~b}$ & $39.8 \%_{c}$ & $38.7 \%$ a,c & $59.2 \% \mathrm{~d}$ \\
\hline $\begin{array}{l}\text { Submitting completed forms } \\
\text { from public sector websites }\end{array}$ & $p<.001$ & $7.5 \%$ a & $10.6 \% a, b$ & $20.9 \%$ b,c & $22.6 \%_{c}$ & $42.8 \% \mathrm{~d}$ \\
\hline $\begin{array}{l}\text { Transferring files between } \\
\text { computers or other devices }\end{array}$ & $p<.001$ & $48.5 \%$ a & $49.7 \%$ a & $57.1 \%$ a & $72.0 \%$ b & $81.2 \% \mathrm{~b}$ \\
\hline
\end{tabular}




\begin{tabular}{|c|c|c|c|c|c|c|}
\hline Variable & $\frac{\frac{0}{3}}{3}$ & 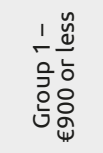 & 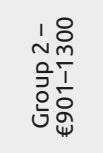 & 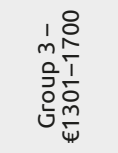 & 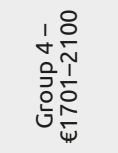 & 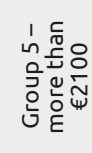 \\
\hline $\begin{array}{l}\text { Installing software or applications } \\
\text { (apps) }\end{array}$ & $p<.001$ & $31.3 \%$ a & $27.5 \%$ a & $34.6 \% a, b$ & $47.6 \% \mathrm{~b}, \mathrm{c}$ & $59.6 \%$ \\
\hline $\begin{array}{l}\text { Changing the settings of any } \\
\text { software }\end{array}$ & $p<.001$ & $16.4 \%$ a & $15.9 \%$ a & $20.9 \% a, b$ & $33.3 \% \mathrm{~b}, \mathrm{c}$ & $41.6 \%$ \\
\hline Copying or moving files or folders & $p<.001$ & $58.2 \%$ a & $58.2 \%$ a & $60.2 \%$ a & $76.2 \% b$ & $84.0 \% \mathrm{~b}$ \\
\hline Using word processing software & $p<.001$ & $55.2 \%$ a & $59.3 \%$ a & $61.8 \% \mathrm{a}$ & $77.4 \% \mathrm{~b}$ & $86.4 \%$ \\
\hline Using spreadsheet software & $p<.001$ & $41.0 \%$ a & $42.9 \% \mathrm{a}$ & $49.2 \% a, b$ & $58.9 \% \mathrm{~b}$ & $74.0 \%$ \\
\hline $\begin{array}{l}\text { Creating presentations or multi- } \\
\text { object documents }\end{array}$ & $p<.001$ & $24.6 \%$ a & $24.3 \%$ a & $33.0 \% a, b$ & $47.0 \%$ b,c & $56.8 \% c$ \\
\hline $\begin{array}{l}\text { Using software to edit photos, } \\
\text { video or audio files }\end{array}$ & $p<.001$ & $25.4 \%$ a & $29.1 \%$ a & $38.7 \% a, b$ & $48.2 \% \mathrm{~b}, \mathrm{c}$ & $56.0 \%$ \\
\hline
\end{tabular}

Note: Values with the same subscript letter are not significantly different.

Source: Author

Another important parameter in digital inequality research is age. It is quite obvious that young digital natives can handle the technology better than the older generations, but the question is which technology and to what extent. We conducted a point-biserial correlation to estimate the strength of the linear relationship between a pair of variables, one of them being age, with the other being a measured variable. We only report the results for those variables (others were left out of this part of our analysis) that satisfy the following assumptions:

- each tested pair have one variable that is continuous (age), with the other being dichotomous (natural dichotomy),

- the continuous variable has no significant outliers in either group of the dichotomous variable as assessed by the inspection of a boxplot ${ }^{2}$; they might have outliers that are neither data entry nor measurement errors, nor unusual values, and represent small but explainable personal situations of individuals, therefore they were kept in the analysis of the data ${ }^{3}$

- each case has values for both paired variables,

- the variance of the continuous variable in each group of the dichotomous variable is equal (Levene's test for the equality of variances, $<.005$ ), and

2 We conducted an additional test by removing the outliers, but gained similar results.

3 Outliers (values greater than 1.5 box-lengths from the edge of the boxplot box) were detected in 7 variables and 13 respondents, all of them very young or very old, showing that some older individuals might be just more IT savvy and some younger individuals reject IT for some reason. For example, 3 respondents (aged 58, 59, and 66) program, 1 respondent (aged 73) installs application(s), 1 respondent (aged 73) uses online storage (the cloud), 2 respondents (aged 65 and 67) create websites or write blogs, 5 respondents (aged 20, 22 and 23) do not use a smartphone, 2 respondents (aged 73 and 74) play online games, and 1 respondent (aged 73) uses social networks. 
- the continuous variable is normally distributed in each group of the dichotomous variable based on inspection of the Q-Q plots.

The results of the point-biserial correlation carried out regarding age and engagement show a few significant differences (data are the mean \pm the standard deviation), as presented in Table 6. For explanatory purposes, we describe the first row as a statistically significant correlation between age and laptop usage, $r_{p b}(38)=.144, p<.001$, with participants using a laptop computer being at a younger average age than non-users (40.55 \pm 14.14 versus $45.13 \pm 15.15)$. Laptop usage accounted for $2.1 \%$ of the variability in age.

Table 6. Statistically significant correlations between age and measured dependent variables using the point-biserial correlation method. Other variables do not pass the assumptions of this method.

\begin{tabular}{|c|c|c|c|c|c|c|c|}
\hline Variable & $\begin{array}{l}\stackrel{*}{0} \\
\frac{0}{3} \\
\stackrel{0}{2} \\
0\end{array}$ & $\stackrel{\tilde{y}}{z}_{z}^{\tilde{z}}$ & $\begin{array}{l}\stackrel{\circ}{z} \\
z\end{array}$ & 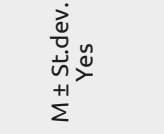 & 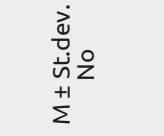 & * ${ }^{*} 8$ & 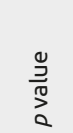 \\
\hline $\begin{array}{l}\text { Using the internet on a laptop } \\
\text { or notebook }\end{array}$ & $p=.065$ & 791 & 347 & $40.55 \pm 14.14$ & $45.13 \pm 15.15$ & 0.144 & $<.001$ \\
\hline $\begin{array}{l}\text { Finding info on goods and } \\
\text { services }\end{array}$ & $p=.383$ & 969 & 169 & $41.32 \pm 14.44$ & $45.54 \pm 15.05$ & 0.103 & .001 \\
\hline $\begin{array}{l}\text { Reading online news / } \\
\text { newspapers / news magazines }\end{array}$ & $p=.326$ & 902 & 236 & $41.41 \pm 14.46$ & $43.98 \pm 14.99$ & 0.071 & .016 \\
\hline $\begin{array}{l}\text { Telephoning over the internet / } \\
\text { making video calls }\end{array}$ & $p=.994$ & 471 & 667 & $37.54 \pm 14.27$ & $45.06 \pm 14.03$ & 0.254 & $<.001$ \\
\hline $\begin{array}{l}\text { Uploading self-created content } \\
\text { to be shared }\end{array}$ & $p=.874$ & 364 & 774 & $36.93 \pm 14.26$ & $44.30 \pm 14.17$ & 0.236 & $<.001$ \\
\hline Participating in social networks & $p=.879$ & 556 & 582 & $35.59 \pm 13.31$ & $48.02 \pm 13.13$ & 0.426 & $<.001$ \\
\hline Playing or downloading games & $p=.277$ & 267 & 871 & $35.69 \pm 14.11$ & $43.86 \pm 14.22$ & 0.237 & $<.001$ \\
\hline $\begin{array}{l}\text { Listening to music (e.g. web } \\
\text { radio, music streaming) }\end{array}$ & $p=.284$ & 546 & 592 & $37.35 \pm 13.7$ & $46.18 \pm 14.13$ & 0.302 & $<.001$ \\
\hline $\begin{array}{l}\text { Submitting completed forms } \\
\text { from public sector web sites }\end{array}$ & $p=.055$ & 257 & 881 & $40.07 \pm 13.68$ & $42.49 \pm 14.83$ & 0.069 & .020 \\
\hline $\begin{array}{l}\text { Transferring files between } \\
\text { computers or other devices }\end{array}$ & $p=.927$ & 722 & 416 & $38.53 \pm 13.93$ & $47.88 \pm 13.84$ & 0.308 & $<.001$ \\
\hline $\begin{array}{l}\text { Copying or moving files or } \\
\text { folders }\end{array}$ & $p=.251$ & 782 & 356 & $38.91 \pm 14.12$ & $48.61 \pm 13.4$ & 0.308 & $<.001$ \\
\hline Using word processing software & $p=.233$ & 805 & 333 & $39.62 \pm 14.38$ & $47.57 \pm 13.59$ & 0.248 & $<.001$ \\
\hline $\begin{array}{l}\text { Creating presentations or multi- } \\
\text { object documents }\end{array}$ & $p=.231$ & 444 & 694 & $35.83 \pm 13.46$ & $45.85 \pm 13.96$ & 0.335 & $<.001$ \\
\hline $\begin{array}{l}\text { Using advanced functions of } \\
\text { spreadsheet software }\end{array}$ & $p=.393$ & 470 & 155 & $38.30 \pm 13.46$ & $41.03 \pm 14.31$ & 0.086 & .031 \\
\hline
\end{tabular}

* The $p$ value of Leven's test for the equality of variances for engagement scores for Yes/No answers.

** Statistically significant coefficient value.

*** Sig. (2-tailed) value of the Pearson Correlation table of the point-biserial correlation coefficient, $r_{p b}$. Source: Author 


\section{Discussion}

The topic of digital inequality is more important today than it has ever been in the past. In the digital convergence of today's society, information technology is one of the key parameters of social inclusion, innovation, and progress. Empirical research has even shown that digital inclusion can change individuals' lives (Broadbent \& Papadopoulos, 2013). In this paper, we focused on three levels of digital inequality. The basic level of digital inequality, i.e. internet access, has been the most known and discussed level for decades and remains significant even today. In most of the developed world, nearly $100 \%$ internet coverage exists today (Slovenia plans to achieve this by 2020), thus gradually removing the obstacle to internet access (World Economic Forum, 2016). Nevertheless, availability does not mean use, which is influenced today mainly by income factors (the data from the global NRI Index 2016 shows a statistically significantly strong correlation between the income group of the country and the percentage of individuals using the internet in that country $(r(141)=.877, p<.001)$. Although we can see that devices and internet access are becoming cheaper every day, today's business and personal environment demand different access channels, a number of different devices (mobile and fixed), and various software. Within households, each member demands his or her own device (not like a TV was used in the past), using them simultaneously and for different internet services, therefore demanding fast broadband connections. Nonetheless, with the advancement of internet speed and the reduced prices of broadband access, the idea of universal internet access has become a given (in some countries, even a constitutional right). So the more crucial issues stem from the higher levels of digital inequality. The results of our empirical research show that internet use in Slovenia is below the EU average, but still high on the global scale. We detected no statistically significant divide as regards the aspect of gender, but determined that household income is an issue that persists in Slovenia, with households in the highest class having almost double the number of internet users compared to the lowest income class, thus showing similar results as other researchers (Rohman \& Bohlin, 2013; Weiss et al., 2016).

In today's development of computers, smart phones, and the corresponding applications, a great deal of attention is devoted to the simplicity of devices and user experience. But this technology is much more complex compared to the technologies of the past, such as radio, television, or typewriters, and the demand as to a certain level of digital skills causes a second level of inequality. Digital skills are therefore essential since digital inclusion improves individuals' communication potential and information gathering, and leads to a higher level of self-esteem (Broadbent \& Papadopoulos, 2013). Anderson (2008) goes even further in proving that digital skills and literacy are linked to the knowledge that is the foundation of the knowledge society of today. Our results show that users develop skills for the services they are interested in, but at the same time indicate skill obstacles e.g. as regards using digital 
signatures. Significant gender differences map with the existing general social gender differences, but show more situations where women have fewer digital skills and use IT less compared to men. This might also relate to the concept of men being more technical than women in general, as described by Van Dijk (2012). A digital gender gap is noted also by the International Telecommunication Union, which found a smaller gap not favouring women in the developed world (2.3\%), but which is wider in the developing world (7.6\%) (International Telecommunication Union, 2016). We must also stress the inequalities that arise from one's cultural-social background and income. In all cases where significant income group differences were detected, higher household income groups showed a higher level of digital skills. White and Selwyn (2013) also determined that individuals from higher socio-economic classes show higher levels of digital skills primarily due to the better internet accessibility options linked to financial resources. Considering age differences, the results showed that non-users of specific online services or those without specific digital skills are on average older than users (except for the submission of online forms for making an appointment with a general practitioner). The highest differences in favour of younger persons concerned the usage of presentation software, digital skills for moving data between devices, and copying/moving files and folders. Research also shows that digital natives are more IT savvy and outdo the older generations, but lack the more advanced skills (informational and strategic skills) (Van Dijk, 2012). We must, however, agree with Van Dijk (2012) that the reported digital skills inequality is measured based on the self-generated opinion of the respondents, which is not realistic and often different from the results of real skill test that are sometimes performed in parallel with surveys.

The third level of digital inequality discussed is level of IT use. Gangadharani and Byrum (2012) define meaningful use of the internet as a key success element of digital inclusion. The question is what is meaningful use. For each individual user this may be something different and at the same time is mostly dependant on his or her general or other needs and the surrounding sociocultural environment. In our research, we found differences influenced by age and social characteristics. In general, all statistically significant differences showed that higher income groups had a higher level of internet use. In comparing 'the poorest with the richest', the latter stand out as regards money management (online banking services) and spending (online travel services), on one hand, and much higher use of e-government forms and services, on the other (i.e. they are able to take advantage of their skills when more demanding technology, such as digital signatures, is required). Considering age, the highest differences in favour of the younger generations concerned social network participation and listening to music online.

Finally, indexes and models that attempt to describe the third level of digital inequality, i.e. the use level, very often miss the crucial element, i.e. the impact. We agree with Misuraca et al. (2013) that because of inadequate 
measurement models it is not possible to thoroughly evaluate digital inequality and its impact on society. This 'imperfection' can also be noted in our research questionnaire and European benchmarking models, such as the DESI Index. These models need to be extended in such a manner that would include socio-economic impact measures of digital inclusion. While many indexes are intended to show digital inequality, they do not show the reasons for such nor the impacts thereof. Therefore, it is only logical that the states and institutions that conduct such measurements should include such additional indexes. It is only with comprehensive models that they would be able to efficiently set and direct their strategies and policy in the direction of universal digital inclusion and equality. Therefore, our proposed model includes 4th and 5th levels of inequality that should be measured in order to gain a holistic view of the problem. The indexes are still to be defined.

We can conclude our discussion by agreeing with the Digital Slovenia 2020 strategy that it is only by removing the identified gaps in digital accessibility, skills, and level of IT use that it will be possible to guarantee the full scope of digital services to all citizens, and thus positively influence their lives. Nonetheless, it has to be stressed that these activities addressing digital inequality would only enable a narrowing of the digital gap per se. It is only a synergy of strategies and policies on the digital and socio-economical level that would ensure positive results in a country or more broadly. Most of the research, including this study, show a significant relationship and even codependence regarding the mentioned areas.

\section{Limitations}

This empirical research was based on an existing questionnaire and therefore could not be adapted to the particular needs thereof. The proposed model, based on five levels of digital inequality, was therefore not tested and is a 'work in progress'. Future research in this area should focus on the use of information technology in relation to general life events and activities in the direction toward improving the life of individuals and households. In such a manner, the right policies and strategies could be implemented in terms of general inclusion and technology convergence.

As the research sample constitutes a representative sample of one country, namely Slovenia, the results are a reflection of the situation in one country only. To obtain more generally valid results, additional countries would have to be included in the future research.

\section{Conclusion}

This paper and its analysis focus on the research of digital inequality, suggesting a five-level model of digital inequality in the theoretical section. The empirical section presents the current situation as regards Slovenian households and contributes to an understanding of digital inequality 
in the modern society of a developed country. The results concerning individuals and households are important since they enable linking and comparison to other important research studies in the area of digital inequality that focus on a similar population and less on the working or business environment (Sparks, 2013). The results showed the impact of various social parameters, including age, gender, and household income. As regards gender, the results correlate with the results of other researchers (White \& Selwyn, 2013; Yates, Kirby \& Lockley, 2015), which have all found diminishing gender differences as to digital inequality in the developed world. Our results do show some significant differences that could be explained by some general Western society parameters. Males are more likely to play games, watch TV, and write code. On the other hand, women are more likely to search for healthrelated information on the internet and communicate by e-mail. At the same time, the differences considering age are somehow also self-explanatory. The younger population shows enthusiasm for communication technology and services, the adult working-age population for financial and other life-event services, and the older population for health-related and leisure services. Considering the impact of age, some researchers also claim that even with the aging (and of course 'renewal') of the population, these aspects do not change much (Van Deursen et al., 2016). What remains critical and crucial is the finding that inequalities are caused by social or financial reasons. Due to the proven relationship between socio-economic status and digital inequality (Weiss et al., 2016), mainly the state and its politicians must work towards achieving a smaller economic divide in such a manner that those who need more are provided more. We also agree with Sparks (2013) that research in the field of digital inequality is needed in the future since it coexists with and even deepens socio-economic inequality, which hinders the progress of society as such.

The results show that more needs to be done to ensure that Slovenia and its population will reap the benefits of the knowledge society. Digital inequality is still present and Slovenia continues to achieve low scores on different international rankings, which can be explained by its inadequate investment in efforts, political will, and financial resources in this area. At the same time, this entails a failure of the previous and existing digital strategies and the policies of this and previous Governments. Nevertheless, the question remains whether digital inclusion itself does not in fact create a new social gap as to inequality, which will be a key problem or challenge as regards the future challenge of ensuring universal internet availability and its socioeconomic imapct (Nguyen, 2012). Therefore, the next step for Slovenia is to initiate a nationwide campaign to increase digital skills, including a change in formal education programmes from primary school onwards, and digital lifelong learning initiatives. As stressed by Evangelista et al. (2014), who carried out wide-ranging research amongst numerous European countries, digital inclusion will enable growth, decrease unemployment, and help narrow the gap between the more favoured and marginal parts of modern society. 


\section{Acknowledgment}

The dataset and the source thereof were provided by the Statistical Office of the Republic of Slovenia. The results and conclusions are not those of the Statistical Office of the Republic of Slovenia or any of the national statistical or other authorities whose data have been used.

Mitja Dečman, PhD, works as an assistant professor at the informatics department of University of Ljubljana, Faculty of Administration where he successfully supplements pedagogical activities with research and at the same time works or leads projects at the Faculty of Public Administration, on the Slovenian or European level. His research field that started with a focus on software and hardware development on his graduate and masters studies at the Faculty of Computer Science is expanding into new areas of informatics, information system development, e-government and in the last years into the area of security of e-business, digital signatures, long-term digital preservation and the aspects of authenticity. He is the author and coauthor of many papers from abovementioned fields, lecturer at seminars and workshops within the Faculty of Administration and outside of it. 


\section{References}

Agency for communication networks and services of the Republic of Slovenia (2017). The 4th quarter 2016: the report on the development of electronic communication market. Retrieved from http://www.akos-rs.si/cetrtocetrtletje-2016:-porocilo-o-razvoju-trga-elektronskih-komunikacij

Anderson, R. E. (2008). Implications of the information and knowledge society for education. In J. Voogt \& G. Knezek (Eds.), International Handbook of information technology in primary and secondary education (pp. 5-22). New York: Springer.

Andreasson, K. (2015). Digital Divides: The New Challenges and Opportunities of e-Inclusion. CRC Press.

Bangemann, M., et al. (1994). Recommendations to the European Council: Europe and the global information society. Brussels: European Commission. Retrieved from https://pdfs.semanticscholar.org/982c/9387a3e874c0ebc94a8c2529ad 40a8b8c5f7.pdf

Bannister, F. (2007). The curse of the benchmark: an assessment of the validity and value of e-government comparisons. International Review of Administrative Sciences, 73(2), 171-188.

Brandtzæg, P. B., Heim, J., \& Karahasanović, A. (2011). Understanding the new digital divide-A typology of Internet users in Europe. International Journal of Human-Computer Studies, 69(3), 123-138. doi: 10.1016/j.ijhcs.2010.11.004

Broadbent, R., \& Papadopoulos, T. (2013). Bridging the digital divide-An Australian story. Behaviour \& Information Technology, 32(1), 4-13.

Castells, M. (2011). The Rise of the network society: The information age: Economy, society, and culture. John Wiley \& Sons.

Czernich, N., Falck, O., Kretschmer, T., \& Woessmann, L. (2011). Broadband Infrastructure and Economic Growth. The Economic Journal, 121(552), 505532. doi: 10.1111/j.1468-0297.2011.02420.x

DiMaggio, P., Hargittai, E., Celeste, C., \& Shafer, S. (2004). From unequal access to differentiated use: A literature review and agenda for research on digital inequality. In K. Neckermann (Ed.), Social Inequality (pp. 355-400). New York: Russell Sage Foundation.

Duff, A. S. (2013). Information society studies. Routledge.

Ebbers, W. E., Jansen, M. G. M., \& van Deursen, A. J. A. M. (2016). Impact of the digital divide on e-government: Expanding from channel choice to channel usage. Government Information Quarterly, 33(4), 685-692. doi: 10.1016/j.giq.2016.08.007

Edelstein A., Bowes J. in Harsel S. (Eds.) (1978). Information societies: Comparing the Japanese and American experiences. Seattle: School of Communications, University of Washington.

European Commission. (2017). Digital Economy and Society Index (DESI) 2017, Methodological note. Retrieved from http://ec.europa.eu/newsroom/ document.cfm?doc_id=43048

Eurostat. (2016). ICT specialists in employment - Statistics Explained. Retrieved 4 June 2017, from http://ec.europa.eu/eurostat/statistics-explained/index. php/ICT_specialists_in_employment\#Main_statistical_findings

Evangelista, R., Guerrieri, P., \& Meliciani, V. (2014). The economic impact of digital technologies in Europe. Economics of Innovation and New Technology, 23(8), 802-824. doi: 10.1080/10438599.2014.918438 
Gangadharan, S. P., \& Byrum, G. (2012). Introduction: Defining and measuring meaningful broadband adoption. International Journal of Communication, 6 , 2601-2608.

Government of the Republic of Slovenia. (2016). Development Strategy for the Information Society until 2020. Retrieved from http://www.mju.gov. si/fileadmin/mju.gov.si/pageuploads/DID/Informacijska_druzba/pdf/ DSI_2020_3-2016_pic1.pdf

Government of the Republic of Slovenia. (2016). Next-Generation Broadband Network Development Plan to 2020. Retrieved from http://www.mju.gov.si/ fileadmin/mju.gov.si/pageuploads/DID/Informacijska_druzba/NGN_2020.pdf

Gunkel, D. J. (2003). Second thoughts: toward a critique of the digital divide. New Media \& Society, 5(4), 499-522.

Hargittai, E. (2010). Digital Na(t)ives? Variation in Internet Skills and Uses among Members of the "Net Generation". Sociological Inquiry, 80(1), 92-113. doi: 10.1111/j.1475-682X.2009.00317.x

International Telecommunication Union. (2016). Measuring the information society 2016. International Telecommunication Union Report. Geneva, Switzerland: United Nations. Retrieved from https://www.itu.int/en/ITU-D/ Statistics/Documents/publications/misr2016/MISR2016-w4.pdf

Karpov, A. O. (2017). The Problem of Separating the Notions of "Knowledge" and "Information" in the Knowledge Society and its Education. Procedia-Social and Behavioral Sciences, 237, 804-810. doi: 10.1016/j.sbspro.2017.02.152

Kymäläinen, T. (2016). Science fiction prototypes as a method for discussing socio-technical issues within emerging technology research and foresight. Athens Journal of Technology \& Engineering (ATINER). Retrieved from https:// www.athensjournals.gr/technology/2016-3-4-4-Kymalainen.pdf

Loader, B. (1998). Cyberspace divide: Equality, agency, and policy in the Information Society. Psychology Press.

Mehmood, B., Rehman, H., \& Haider Rizvi, S. H. (2014). From Information Society to Knowledge Society: The Asian perspective. Pakistan Journal of Information Management \& Libraries (PJIM\&L), 15(0). Retrieved from http://journals. pu.edu.pk/journals/index.php/pjiml/article/view/759

Misuraca, G., Codagnone, C., \& Rossel, P. (2013). From practice to theory and back to practice: Reflexivity in measurement and evaluation for evidencebased policy making in the Information Society. Government Information Quarterly, 30( Supplement 1), S68-S82. doi: 10.1016/j.giq.2012.07.011

Morganti, Karen Donders, L., Katz, R., Koutroumpis, P., \& Martin Callorda, F. (2014). Using a digitization index to measure the economic and social impact of digital agendas. Info, 16(1), 32-44.

Nguyen, A. (2012). The digital divide versus the 'digital delay': Implications from a forecasting model of online news adoption and use. International Journal of Media \& Cultural Politics, 8(2-3), 251-268. doi: 10.1386/macp.8.2-3.251_1

OECD. (2010). The economic impact of ICT: Measurement, evidence and implications. Paris: OECD.

OECD. (2011). OECD guide to measuring the Information Society 2011. Paris: OECD.

PEW. (2008). Pew Internet and American Life Project, 2008 Tracking Survey. Washington, D.C.: Pew Internet and American Life Project. 
Robinson, L. (2012). Information-Seeking 2.0. The effects of informational advantage. RESET. Recherches En Sciences Sociales Sur Internet, (1). Retrieved from http://reset.revues.org/135

Robinson, L., Cotten, S. R., Ono, H., Quan-Haase, A., Mesch, G., Chen, W., ... Stern, M. J. (2015). Digital inequalities and why they matter. Information, Communication \& Society, 18(5), 569-582.

Rohman, I. K., \& Bohlin, E. (2013). The impact of broadband speed on the household income: comparing OECD and brics. Retrieved from https://papers.ssrn.com/ sol3/papers.cfm?abstract_id=2226899

Savoldelli, A., Misuraca, G., \& Codagnone, C. (2013). Measuring the Public value of e-Government: The eGEP2. 0 model. Electronic Journal of E-Government, 11(1), 373-388.

Schradie, J. (2011). The digital production gap: The digital divide and Web 2.0 collide. Poetics, 39(2), 145-168.

Servaes, J., \& Oyedemi, T. (2016). Social inequalities, media, and communication: theory and roots. Lanham, USA: Lexington Books.

Sparks, C. (2013). What is the "Digital Divide" and why is it important? Javnost The Public, 20, 27-46. doi: 10.1080/13183222.2013.11009113

Stehr, N. (2007). Societal transformations, globalisation and the knowledge society. International Journal of Knowledge and Learning, 3(2-3), 139-153. doi: 10.1504/IJKL.2007.015548

Tilly, C. (1998). Durable inequality. Univ of California Press. Retrieved from https://www.google.com/books?hl=en\&lr=\&id=SRcjUymz5cMC\&oi=fnd\&pg= PP9\&dq=Charles+Tilly,+Durable+Inequality,+University+of+California+Press+ Berkeley,+Los+Angeles,+London:\&ots=zJwmXaY7uT\&sig=84erL1qFhQ46t73 DFKkziC10Q5C

Van Deursen, A. J., Helsper, E. J., \& Eynon, R. (2016). Development and validation of the Internet Skills Scale (ISS). Information, Communication \& Society, 19(6), 804-823.

van Deursen, A., \& Van Dijk, J. (2011). Internet skills and the digital divide. New Media \& Society, 13(6), 893-911. doi: 10.1177/1461444810386774

Van Dijk, J. (2005). The deepening divide: Inequality in the information society. Sage Publications. Retrieved from https://www.google.com/books?hl=en\&lr=\&id= AwGJCgAAQBAJ\&oi=fnd\&pg=PA1\&dq=VAN+DIJK,+Jan+A.+G.+M.+(2005).+T he+Deepening+Divide:+Inequality+in+the+Information+Society,+Thousand+ Oaks,+Sage.\&ots=vICdOoam18\&sig=ABgFRD7xHsHsC_8brL75OkkL-vc

Van Dijk, J. (2012). The Evolution of the Digital Divide. In Digital Enlightenment Yearbook 2012. IOS Press. Retrieved from https://www.utwente.nl/ bms/vandijk/news/The\%20Evolution\%20of\%20the\%20Digital\%20 Divide/Evolution\%20of\%20the\%20Digital\%20Divide\%20Digital\%20 Enlightment\%20Yearbook\%202012.pdf

Van Dijk, J., \& Hacker, K. (2003). The digital divide as a complex and dynamic phenomenon. The Information Society, 19(4), 315-326.

Webster, F. (2014). Theories of the Information Society. New York, USA: Routledge.

Weiss, J. W., Yates, D. J., \& Gulati, G. J. J. (2016). Affordable Broadband: Bridging the Global Digital Divide, a Social Justice Approach. In 2016 49th Hawaii International Conference on System Sciences (HICSS) (pp. 3848-3857). doi: 10.1109/HICSS.2016.480 
Wessels, B., Finn, R., Wadhwa, K., Bigagli, L., Nativi, S., \& Noorman, M. (2016). Mobilising data in a knowledge society. In EGU General Assembly Conference Abstracts (Vol. 18, p. 17799). Retrieved from http://adsabs.harvard.edu/ abs/2016EGUGA..1817799W

White, P., \& Selwyn, N. (2013). Moving on-line? An analysis of patterns of adult Internet use in the UK, 2002-2010. Information, Communication \& Society, 16(1), 1-27.

Whitmore, A. (2012). A statistical analysis of the construction of the United Nations e-government development index. Government Information Quarterly, 29(1), 68-75.

Witte, J. C., \& Mannon, S. E. (2010). The internet and social inequalitites. New York, USA: Routledge.

World Bank (1999). Knowledge for development: World development report. New York: Oxford University Press.

World Economic Forum. (2016). Global information technology report 2016 Reports - World Economic Forum. Retrieved 25 May 2017, from http:// reports.weforum.org/global-information-technology-report-2016/ networked-readiness-index/

Yates, S., Kirby, J., \& Lockley, E. (2015). Digital Media Use: Differences and Inequalities in Relation to Class and Age. Sociological Research Online, 20(4), 12. doi: $10.5153 /$ sro. 3751

Yu, L. (2011). The divided views of the information and digital divides: A call for integrative theories of information inequality. Journal of Information Science, 37(6), 660-679. doi: 10.1177/0165551511426246 


\subsection{Izvirni znanstveni članek}

\section{Model digitalne neenakosti v družbi znanja: primer Slovenije}

Družbaznanja, kinadgrajuje pojeminformacijske družbe, pojmuje informacijsko tehnologijo (IT) kot tisto, ki je za uporabnika ključna pri dostopu do znanja, hkrati pa uporabnik določeno znanje potrebuje za uporabo tehnologije same. Paradoks povezujemo tudi s pojmom digitalne neenakosti, ki analizira razlike med ljudmi in zaobjema različne ravni, kot so fizični dostop do tehnologije, veščine za uporabo tehnologije in sociološke in kulturne dejavnike ter vplive med in znotraj teh ravni. Čeprav je fenomen digitalne neenakosti star že najmanj dve desetletji, je opazen tudi danes. Digitalna neenakost se kaže predvsem v spolu, ekonomskem statusu in letih. Hkrati pa neenakost lahko opredelimo po različnih ravneh. V članku je predlagan model 5ih ravni digitalne neenakosti, analizirane pa so prve tri. Zaradi uporabe obstoječega vprašalnika iz raziskave Statističnega urada Republike Slovenije zadnjih dveh ravni nismo mogli analizirati, vendar ugotavljamo, da imajo podobne težave raziskovalci tudi drugje. Opažamo, da v zadnjem desetletju počasi narašča zavedanje, da digitalna neenakost ni samo razlikovanje tistih, ki dostopa do interneta ali znanja uporabe interneta nimajo oziroma imajo, temveč da je danes pomembno razlikovanje med tistimi, ki znajo internet s pridom izkoristiti in tistimi, ki jim to ne uspe. Različni indeksi razvitosti družbe znanja ugotavljajo stanje družbe in pripadajočo digitalno neenakost, tako na globalni ravni kot tudi znotraj manjših okolij. Ugotavljamo, da se tudi ti indeksi premalo pogosto navezujejo na politike in strategije, ki naj bi stanje izboljševale, kar privede do neustreznih korakov reševanja digitalne neenakosti.

Pričujoči članek na podlagi analize 1568 vprašalnikov reprezentativnega vzorca prebivalcev Slovenije, pridobljenega od Statističnega urada Republike Slovenije, prikazuje stanje v Sloveniji v letu 2016 in rezultate povezuje s smernicami strategij, ki jih mora ali pa jih razvija Slovenija s ciljem zmanjšati digitalni razkorak v družbi in se v bližnji prihodnosti enačiti z najboljšimi v Evropi in svetu. Raziskava ugotavlja, da je ključen parameter digitalne neenakosti ekonomski status uporabnika, a hkrati opozarja, da mnogi sistemi merjenja niso postavljeni tako, da bi lahko odkrivali ključne izzive digitalne neenakosti. Rezultati kažejo, da Slovenija na ravni družbe znanja zagotovo potrebuje več. Digitalna neenakost je še vedno prisotna, predvsem pa Slovenija ne dosega dobrih rezultatov v mednarodnih indeksih, kar pomeni tudi in predvsem neučinkovitost strategij te in preteklih vlad. Zato je naslednji korak Slovenije izvajanje velikega števila aktivnosti na področju povečevanju digitalnih veščin in usposabljanju tako najmlajših znotraj šolskega formalnega izobraževanja kot odraslih skozi vseživljenjsko učenje. Zato bo, kot je zapisano 
v strategiji Digitalna Slovenija 2020, le z odpravo ugotovljenih vrzeli pri digitalni dostopnosti, pismenosti in veščinah ter uporabi mogoče zagotoviti, da bodo vsem državljanom v polnosti dostopne storitve, ki jih digitalna družba omogoča, ter da le-ti tako postanejo sooblikovalci razvoja digitalne družbe.

Vendar je treba poudariti, da so to vseeno le aktivnosti, ki predvsem neposredno naslavljajo digitalne neenakosti, a premalo upoštevajo socialno neenakost per se. Ugotavljamo, da bo le sinergija strategij na digitalnih področjih s strategijami splošnega izboljšanja socialnega in kulturnega stanja v državi dosegla učinke. Večina zadnjih raziskav, vključno s pričujočo, namreč kažejo kritično povezanost in soodvisnost omenjenih področij. 
